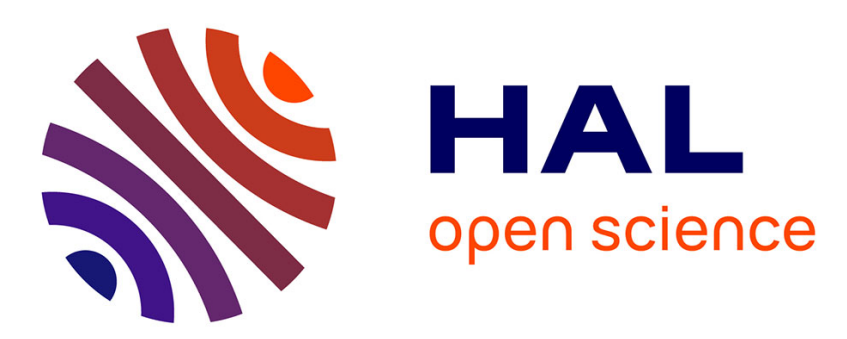

\title{
Influence of phosphorus fertilization and availability on growing and production of sown tomatoes Yann Dumas
}

\section{To cite this version:}

Yann Dumas. Influence of phosphorus fertilization and availability on growing and production of sown tomatoes. Vegetables for processing, Aug 1987, Kecskemet, Hungary. hal-02782317

\section{HAL Id: hal-02782317 \\ https://hal.inrae.fr/hal-02782317}

Submitted on 4 Jun 2020

HAL is a multi-disciplinary open access archive for the deposit and dissemination of scientific research documents, whether they are published or not. The documents may come from teaching and research institutions in France or abroad, or from public or private research centers.
L'archive ouverte pluridisciplinaire HAL, est destinée au dépôt et à la diffusion de documents scientifiques de niveau recherche, publiés ou non, émanant des établissements d'enseignement et de recherche français ou étrangers, des laboratoires publics ou privés. 
Y. Dumas

Station d'Agronomie

INRA

84140 Montfavet

France

\section{Abstract}

For processing tomato, total $\mathrm{P}_{2} \mathrm{O}_{5}$ uptakes are rather low : about $\mathrm{l} \mathrm{kg} /$ ton of fruits. However phosphorus availability and taking easiness are important for the very young plant to enhance flowering precocity; thus, in the South of France, producers bring to soils great quantities of phosphorus which becomes later insoluble in calcareous soils. Now we must try to reduce the cost of production and consequently of fertilization.

Experimerts in pois and in fields have shown that in a clay soil, calca reous and very poor in phosphorus, it is possible to reduce notably phosphorus supply to a sown tomato by localizing it $5 \mathrm{~cm}$ under the seed or even directly on the seed : from the equivalent of $50 \mathrm{~kg} / \mathrm{ha}$ brought as triple superphosphate, we observe a multiplication by almost 10 of the speed of dry matter accumulation until the first trusses, which appear then about ten days before the control. When using ammonium phosphate, the advance is smaller and, with high doses (> $150 \mathrm{~kg} \mathrm{P}_{2} \mathrm{O}_{5} /$ ha, localized) there is a delay with regard to the control, by reason of saltness.

There are no significant differences for yields, except for the control when it meets high temperature conditions in summer ; in the opposite case its yield is equivalent but later with a less concentrated ripening.

\section{Introduction}

In the South of France, the production of tomatoes for processing is going to meet economical difficulties even inside the European Economic Community. It is necessary to keep good yields while reducing the cost of production, like the cost of labour by mechanizing and also the cost of other inputs, like fertilization. This paper will deal with that last point, taking phosphorus as an example.

Many authors, generally working with sand or sandy soils have established that phosphorus availability and taking easiness are important for the very young plant (Baker, 1937 ; Wilcox, 1967 ; Fontes and al., 1984). However, for processing tomato, total $\mathrm{P}_{2} \mathrm{O}_{5}$ uptakes are rather low : about $1 \mathrm{~kg} /$ ton of fruits. Curiously, producers use to bring great quantities of phosphorus (on an average $250 \quad \mathrm{P}_{2} \mathrm{O}_{5} / \mathrm{ha}$ ) to soils which don't nead any for half of the cases ; moreover a large part of the supplied phosphorus becomes later insoluble in calcareous soils (Blanchet et al., 1971, 1982). So, the purpose of our work is to know how and until what level we can reduce the phosphorus supply, even in poor soils, without decreasing to much the yield, in the case of a culture managed mechanically, harvest

$$
\begin{aligned}
& \text { HAPAR H: M160" } \\
& \text { Acta Horticulturae 220, } 1987 \\
& \text { Vegetables for Processing }
\end{aligned}
$$

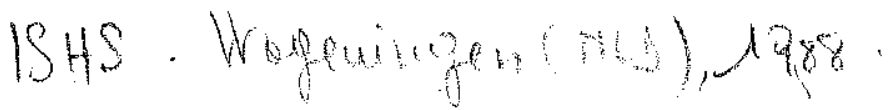


included, with sowing directly in the field and other technics reducing the costs.

\section{Material and methods}

Two types of trials were made : in pots under a glasshouse and in the fields, using bloc designs. The same soil, heavy and calcareous, formed on young alluvial deposits near Avignon, was used in every case ; its characteristics are as follows : clay content $530 \%$, organic matter $20 \%$, total nitrogen $1,2 \%$, exchange capacity $25 \mathrm{me} / 100 \mathrm{~g}$; particularly poor in phosphorus with $0.10 \%, \mathrm{P}_{2} \mathrm{O}_{5}$ (ammonium oxalate extraction), it is well provided with $\mathrm{K}^{+}\left(1.2 \mathrm{me} / 100^{5} \mathrm{~g}\right)$ and $\mathrm{Mg}^{++}(3.0 \mathrm{me} / 100 \mathrm{~g})$. The cultivar of processing tomato was always Earlymech.

2.1. The experiments under glasshouse were managed in 1985-86-87 from february to may, with temperature conditions not far from those met by sown tomatoes in fields. Tomato seeds were placed in pots of $10 \mathrm{kgs}$; three young plants were kept on the line, simulating a density of 12 plants/linear meter on the field. The main used treatments will be presented in paragraphs 3.1 and 3.2 .

2.2. In the field, the area of each plot was about $50 \mathrm{~m}^{2}$. The culture was managed like in large fields with the same equipment as a producer, with the aim of sparing the production factors : mechanizing (simulation for harvest), reducing the inputs, particularly no potassium and only $50 \mathrm{~N} /$ ha, taking in account nitric remainders and soil mineralization.

\section{Results}

\subsection{Advantage of the placement of moderate quantities of phosphorus}

In a pot experiment under glasshouse, various quantities of phosphorus were tested in different types of placement : a) 50-100-150 $\mathrm{P}_{2} \mathrm{O}_{5}$ (equivalent $\mathrm{kg} / \mathrm{ha}$ ) localized under the line, between 7 and $10 \mathrm{~cm}$ from the surface and on a width of $7 \mathrm{~cm}$; b) 50-100-150 localized directly on the seeds on an approximate width of $3 \mathrm{~cm} ;$ c) 50-100-150-200-300 mixed with the upper layer of $0-10 \mathrm{~cm}$; d) $50-100-150-220-330-440-660$ mixed with the whole height of soil in the pot $(0-22 \mathrm{~cm})$. A commercial form of solid triple superphosphate was used.

The first differences could be observed as soon as the coming out of the second true leaf, through the dimensions of the plants (height, length of leaves) and their colour: purple indicates very rapidly a deficiency in phosphorus alimentation.

Table 1 shows the production of aerial dry matter, 35 days after emergence, at the apparition of the first flowers in the earliest treatments. Practically all the localized treatments are equivalent to 660 on $0-22 \mathrm{~cm}$. There is a ratio of 10 between the control and the first group of results (noted a). It appears still larger differences for the accumulation of dry matter in roots. It is also interesting to note that there is roughly a positive relation between the concentration of phosphorus created in the soil near the very young roots and the elaboration of dry aerial matter, which 
illustrates the greater influence of the availability of phosphorus in a very small volume of soil $\left(25 \mathrm{~m}^{3} /\right.$ ha for localizing under the line and $5 \mathrm{~m}^{3}$ on the seeds) than of the quantity brought on a given area.

The speed of leaf area accumulation is considerably increased (figure 1) even with small quantities of phosphorus provided they are localized : so, compared to the control, it is multiplicated by 2 with 50 mixed on $0-10 \mathrm{~cm}$ or on $0-22 \mathrm{~cm}$, which shows that the soil is very poor, but it is multiplicated by 6 with 50 under the line (like with 300 on $0-10 \mathrm{~cm}$ ) and by 8 . with 50 on the seeds (like with 660 on $0-22 \mathrm{~cm}$ ).

When considering development, it can be noted that the degree of availability of phosphorus has, in the same way, a great influence on the date of apparition of the first trusses (maximum deviation of 10 days for the stage 1 truss/plant) and on the speed of apparition of the next trusses (from 0.17 truss/day for the control to 0.75 truss/day for the best treatments). However, after 3 or 4 trusses per plant, the control gets also a high speed of trusses elaboration.

\subsection{Influence of the form of phosphorus}

Several trials with pots under glasshouse have shown the importance of the form of phosphorus on the plant response, comparing superphosphate triple and ammonium phosphate.

When using a solution of ammonium phosphate directly on the seeds, we can observe a reduction of the emergence, increasing with the applied quantity (figure 2), which is not observed with a superphosphate triple. This reduction still exists with a solid fertilizer but is less important.

The table 2, comparing the influence of various quantities of superphosphate or ammonium phosphate on the earliness of the plants ( 4 trusses stage), shows again the favourable influence of a superphosphate supply, even not important and even on a rich soil; but we can see a not so good result when using ammonium phosphate and a very bad effect with high quantities. These desorders may be due to ammonium toxicity which is known to reduce the produced dry weight in sand culture with solution (Wilcox and al., 1985). In our work conditions, we have shown a great increase of the nitrate content, until $600 \mathrm{ppm}$ nitric $\mathrm{N}$, just where the ammonium phosphate (200 kg $\left.\mathrm{P}_{2} \mathrm{O}_{5} / \mathrm{ha}\right)$ was situated and even beneath; this accumulation of nitrates is accompanied of high salinities (until $1.1 \mathrm{~m}$. siemens) which disturb the plant functioning.

\subsection{Field results}

Two simplified experiments were made in the fields in 1985-86 to test localizing under the line compared with enriching the soil on 10 or $15 \mathrm{~cm}$ at the surface tilling. They confirmed the main results presented above, that is the great interest of placing for instance a quantity of $100 \mathrm{P}_{2} \mathrm{O}_{5}$ (superphosphate) under the line from the point of view of flowering eariness, which is important under our climate conditions in order to escape to the high temperatures of the end of july, for they can reduce the yields if culture is still flowering; this gain of flowering earliness 


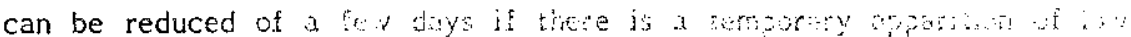
limiting temperatures $\left(<12-13^{\circ} \mathrm{C}\right.$ ) before the first trusss (end of roa. beginning of june), the phosphorus alimentation being reduced whatever the concentration may be (Locascio et al., 1960 ; Cornilion, 1984). It could be noted that high availability of phosphorus had a favourable effect on the maturation earliness (a few days) and grouping, which is good for a harvest by machine.

There were no signifjcant differences for yields $(75 \mathrm{t} / \mathrm{ha})$, except for the control which was handicapped $(65 \mathrm{t} / \mathrm{ha}$ ) when the culture met high temperature conditions in summer limiting flowering and fruit bearing (1986); in the opposite case its yield was equivalent but later and with a less concentrated ripening.

\section{Discussion}

The results presented here confirm the importance of an easy use of phosphorus by the very small root system of young tomatoes. It seems particularly interesting to reach this aim by a judjcious placement of moderate quantities of soluble phosphate in the soil where the young roots will begin to grow. Indeed from a general point of view of efficiency it seems to be a better solution than to enrich the soil with large quantities of $\mathrm{P}$ (Cserni, 1983). In connection with this, the technic which consists to localize in narrow bands phosphorus $5-6 \mathrm{~cm}$ under the line of seeds or directly on the seeds, at a dose of 100 or even $50 \mathrm{~kg} \mathrm{P} \mathrm{O}_{5} / \mathrm{ha}$, for instance, using superphosphate triple rather than ammonium ${ }^{2}$ phosphate, gives good results (from different points of view : a. high speed of production of dry matter and specially of leaf area, which is important for the interception of solar energy but also for the competition against weeds ; b. high speed of formation of roots which is fundamental later for plant alimentation : uptake intensity for potassium depends on the growing speed of the roots and for phosphorus on their length and area (Bosc et al., 1985), provided they are in good conditions of soil profile (favourable structure and moisture); $c$. high speed of formation of trusses which brings a better flowering earliness and can allow a better yield elaboration, more concentrated and avoid high limiting temperature during summer.

The localized phosphate placement on the seeds, 2 or $3 \mathrm{~cm}$ deep, can be executed without any problem when sowing. The placement under the line is to be executed at the last soil preparing: it can appear somf iffi. culties to ger a precise and homogeneous result in a humid heayy clay soil. Nevertheless, in large fields on our clay soil, poor in phosphorus and by localized placement under the seeds, we have shown the possibility of dividing by 2 or 3 the quantities of phosphorus traditionally appljed with a yield of $75-80 \mathrm{t} /$ ha of fruits.

Fox and Kang (1978) working on the phosphorus nutrition of maize on a sandy soil have shown, too, that response to $\mathrm{P}$ fertilization was greatest during early growth and decreased with advanced maturity, but they arrived to the conclusion that no major economics in fertilizer could be achieved as a result of localized placement of phosphorus fertilizer. In fact we had the same type of plant response, but it seems that, with 
sown tomatoes, it is possible to get a satisfying result in culture development and yield while avoiding much wasting. However it is necessary to continue on different types of soils and through various years to confirm or modify these results.

\section{References}

Baker, C.E., 1937. Early fruiting of tomato as induced by the use of soluble phosphate. Proc.Amer.Soc.Hort.Sci. 35:668-672.

Blanchet, R., et al., 1971. Vieillissement d'engrais phosphatés dans le sol et conduite de la fertilisation. Ann.Agron. 22(6):687-703.

Blanchet, R., Bosc, M., Maertens, C., 1982. Les états physico-chimiques du milieu et la nutrition minérale des plantes. Bulletin Technique d'Information 370/372:393-399.

Bosc, M., Callot, G., Jailiard, B., Maertens, C., 1985. Fonctionnement des racines dans le profil de sol. Cultivar, spécial sols et sous-sols, juin $1985, n^{\circ} 184$.

Cornillon, Pa, Maisonneuve, B., 1985. Effet de basses températures appliquées aux parties aérienne ou racinaire de la tomate sur l'absorption d'éléments minéraux et la fertilité pollinique. Agronomie 5(1):33-38.

Cserni, I., 1983. A talaj Al-oldható foszfortartalmának alakulása évenkénti és fetöltő műtrágyázás esetén lepelhomoktalajon. Agrokémia és Talajtan. Tom 32. $n^{\circ}$ 1-2:97-119.

Fontes, C.R., Wilcox, G.E., 1984。 Growth and phosphorus uptake by tomato cultivars as influenced by phosphorus concentrations in soil and nutrient solution. J.Amer.Soc.Hort.Sci. 109(5):633-636.

Fox, R.L., Kang, B.T., 1978. Influence of phosphorus fertilizer placement and fertilization rate on maize nutrition. Soil Science, Vol. $125, n^{\circ} 1$, $34-40$.

Locascio, S.J., Warren, G.F., 1960. Interaction of soil temperature and phosphorus on growth of tomatoes. Proc.Amer.Soc.Hort.Sci. 75:601-610.

Wilcox, G.E., 1967. Effect of phosphorus fertilization on tomato seedling growth rate. Proc.Amer.Soc.Hort.Sci. 90:330-334.

Wilcox, G.E., Magalhaes, J.R., Silva, F.L.I.M., 1985. Ammonjum and nitrate concentrations as factors in tomato growth and nutrient uptake. Journal of Plant Nutrition 8(11):989-998. 
Table 1 - Influence of the applied quantity and the placement of phosphorus (solid superphosphate) on the aerial dry matter production per plant of sown tomatoes 35 days after emergence, in pots under glasshouse

\begin{tabular}{lll} 
Treatment & $\begin{array}{l}\text { Aerial dry } \\
\text { matter } \\
(\mathrm{g})\end{array}$ & $\begin{array}{l}\text { homogeneous } \\
\text { groups }(1)\end{array}$ \\
\hline $100 \mathrm{P}_{2} \mathrm{O}_{5}$ under line & 3.11 & $\mathrm{a}$ \\
$150 \mathrm{P}_{2} \mathrm{O}_{5}$ under line & 3.09 & $\mathrm{a}$ \\
$100 \mathrm{P}_{2} \mathrm{O}_{5}$ on seeds & 3.07 & $\mathrm{a}$ \\
$150 \mathrm{P}_{2} \mathrm{O}_{5}$ on seeds & 2.93 & $\mathrm{a}$ \\
$50 \mathrm{P}_{2} \mathrm{O}_{5}$ on seeds & 2.62 & $\mathrm{ab}$ \\
$660 \mathrm{P}_{2} \mathrm{O}_{5}$ mixed on $0-22 \mathrm{~cm}$ & 2.50 & $\mathrm{ab}$ \\
$50 \mathrm{P}_{2} \mathrm{O}_{5}$ under line & 2.26 & $\mathrm{bc}$ \\
$440 \mathrm{P}_{2} \mathrm{O}_{5}$ mixed on $0-22 \mathrm{~cm}$ & 2.12 & $\mathrm{bc}$ \\
$300 \mathrm{P}_{2} \mathrm{O}_{5}$ mixed on $0-10 \mathrm{~cm}$ & 2.11 & $\mathrm{bc}$ \\
$330 \mathrm{P}_{2} \mathrm{O}_{5}$ mixed on $0-22 \mathrm{~cm}$ & 1.60 & $\mathrm{~cd}$ \\
$150 \mathrm{P}_{2} \mathrm{O}_{5}$ mixed on $0-10 \mathrm{~cm}$ & 1.60 & $\mathrm{~cd}$ \\
$200 \mathrm{P}_{2} \mathrm{O}_{5}$ mixed on $0.10 \mathrm{~cm}$ & 1.33 & de \\
$220 \mathrm{P}_{2} \mathrm{O}_{5}$ mixed on $0-22 \mathrm{~cm}$ & 1.11 & def \\
$150 \mathrm{P}_{2} \mathrm{O}_{5}$ mixed on $0-22 \mathrm{~cm}$ & 0.85 & efg \\
$100 \mathrm{P}_{2} \mathrm{O}_{5}$ mixed on $0-22 \mathrm{~cm}$ & 0.82 & efg \\
$100 \mathrm{P}_{2} \mathrm{O}_{5}$ mixed on $0-10 \mathrm{~cm}$ & 0.80 & efg \\
$50 \mathrm{P}_{2} \mathrm{O}_{5}$ mixed on $0-10 \mathrm{~cm}$ & 0.62 & $\mathrm{fg}$ \\
$50 \mathrm{P}_{2} \mathrm{O}_{5}$ mixed on $0-22 \mathrm{~cm}$ & 0.61 & $\mathrm{fg}$ \\
$0 \mathrm{P}_{2} \mathrm{O}_{5}$ & 0.27 & $\mathrm{~g}$ \\
11 & &
\end{tabular}

(1) Test Newman-Keuls $1 \%$ 
Table 2 - Influence of the quantity and the form of phosphorus placed $5 \mathrm{~cm}$ under the line of tomato seeds on the earliness of the 4 trusses stage per plant (delay in days in reference to the earliest treatments noted zero)

\begin{tabular}{|c|c|c|c|c|c|c|}
\hline \multirow[t]{2}{*}{ Treatments } & \multicolumn{6}{|c|}{$\begin{array}{l}\text { Delay of apparition of the } 4 \text { trusses } \\
\text { stage per plant (days) }\end{array}$} \\
\hline & 0 & 3 & 8 & 12 & 15 & 22 \\
\hline Control : $0 \mathrm{P}_{2} \mathrm{O}_{5}$ & & 0 & & $x$ & & \\
\hline $\begin{array}{l}\text { Triple superphosp } \\
\text { (equivalent } \mathrm{kg} / \mathrm{ha} \text { ) } \\
50 \mathrm{P}, \mathrm{O}_{5}\end{array}$ & 0 & $x$ & & & & \\
\hline $100 \mathrm{P}_{2} \mathrm{O}_{5}$ & 0 & $x$ & & & & \\
\hline $150 \mathrm{P}_{2} \mathrm{O}_{5}$ & $x$ & & & & & \\
\hline $200 \mathrm{P}_{2} \mathrm{O}_{5}$ & $x$ & & & & & \\
\hline
\end{tabular}

ammonium phosphate

(equivalent $\mathrm{kg} / \mathrm{ha}$ )

$50 \mathrm{P}_{2} \mathrm{O}_{5}$
$100 \mathrm{P}_{2} \mathrm{O}_{5}$

o $x$

$150 \mathrm{P}_{2} \mathrm{O}_{5}$

$\mathrm{x}$

$200 \mathrm{P}_{2} \mathrm{O}_{5}$

$x$ : previous soil content : 100 pprn $\mathrm{P}_{2} \mathrm{O}_{5}$

o: previous soil content: $300 \mathrm{ppm} \mathrm{P}_{2} \mathrm{O}_{5}$ 


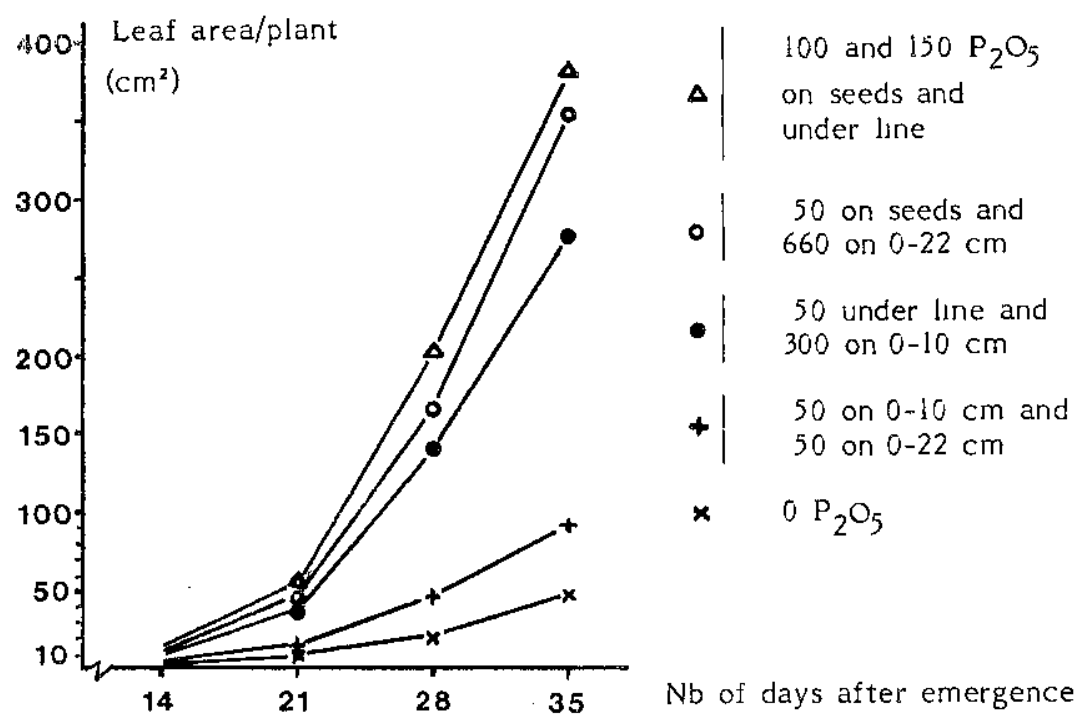

Figure 1 - Evolution of leaf area of tomato seedings and applied quantity and placement of solid superphosphate

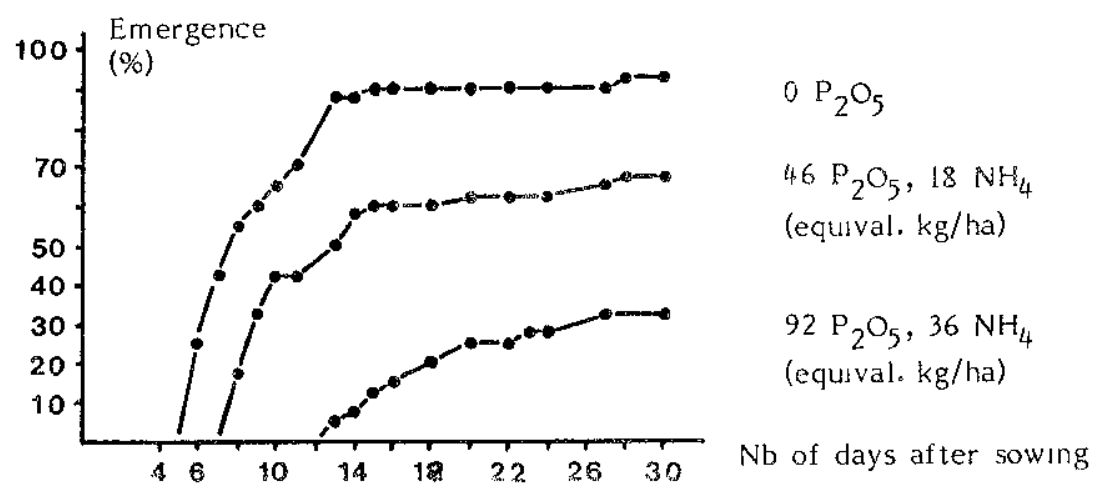

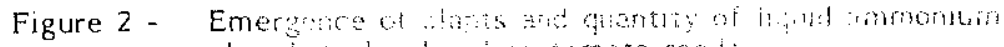

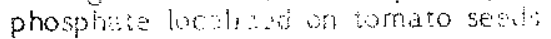

